\title{
Developing Cotton IPM by Conserving Parasitoids and Predators of The Main Pest
}

\author{
NURINDAH* AND DWI ADI SUNARTO \\ ${ }^{1)}$ Indonesian Tobacco and Fibre Crops Research Institute (IToCRI) \\ P.O. Box 199, Malang, Indonesia
}

(received Mei 2011, accepted Juli 2011)

\begin{abstract}
ABSTRAK
Mengembangkan Pengendalian Hayati Terpadu Kapas dengan Konservasi Parasitoid dan Predator Hama Utama. Pada awal pengembangan kapas di Indonesia secara intensif, serangga hama merupakan satu aspek yang penting dalam budidaya kapas, sehingga dilakukan penyemprotan insektisida kimia sintetik secara berjadwal. Frekuensi penyemprotan adalah 7 kali dengan menggunakan $12 \mathrm{~L}$ insektisida per hektar per musim. Pengembangan PHT pada tanaman kapas ditekankan pada metode pengendalian non-kimiawi melalui optimalisasi peran musuh alami dalam pengendalian hama utama kapas (Amrasca biguttulla (Ishida) dan Helicoverpa armigera (Hübner)). Konservasi parasitoid dan predator dengan menyediakan lingkungan yang mendukung perkembangan populasinya merupakan tindakan optimalisasi musuh alami tersebut sehingga dapat menjadi faktor mortalitas biotik yang efektif bagi serangga hama. Konservasi parasitoid dan predator dapat dilakukan melalui perbaikan bahan tanaman dan teknik budidaya, yaitu penggunaan varietas kapas tahan wereng kapas, sistem tanam kapas tumpangsari dengan palawija, penggunaan mulsa, menerapkan konsep ambang kendali dengan mempertimbangkan keberadaan musuh alami, dan penggunaan insektisida botani, jika diperlukan. Konservasi parasitoid dan predator dalam PHT tanaman kapas dapat mengendalikan serangga hama kapas tanpa aplikasi insektisida kimia untuk mendapatkan produksi kapas berbiji yang sama dengan cara pengendalian menggunakan insektisida kimia, sehingga dapat meningkatkan pendapatan petani.
\end{abstract}

KATA KUNCI: Gossypium hirsutum, konservasi, tindakan ambang batas, musuh alami, PHT

\begin{abstract}
Developing Cotton IPM by Conserving Parasitoids and Predators of The Main Pest. On early development of intensive cotton program, insect pests were considered as an important aspect in cotton cultivation, so that it needed to be scheduled sprays. The frequency of sprays was 7 times used $12 \mathrm{~L}$ of chemical insecticides per hectare per season. Development of cotton IPM was emphasized on non-chemical control methods through optimally utilize natural enemies of the cotton main pests (Amrasca biguttulla (Ishida) Helicoverpa armigera (Hübner)). Conservation of parasitoids and predators by providing the environment that support their population development is an
\end{abstract}

\footnotetext{
*Korespondensi:

Telp.: +62-342-492447, Faks: +62-34- 485121,

Email: nurindah@litbang.deptan.go.id
} 
act of supporting the natural enemies as an effective biotic mortality factor of the insect pests. The conservation could be done by improving the plant matter and cultivation techniques that include the use of resistant variety to leafhopper, intercropping cotton with secondary food plants, mulch utilization, using action threshold that considered the presence of natural enemies, and application of botanical insecticides, if needed. Conservation of parasitoids and predators in cotton IPM could control the insect pests without any insecticide spray in obtaining the production of cotton seed. As such, the use of IPM method would increase farmers' income.

KEY WORDS: Gossypium hirsutum, conservation, action threshold, natural enemies, IPM

\section{INTRODUCTION}

Cotton (Gossypium hirsutum) is not originally in Indonesia. The crop has been growing to fulfill the need of national textile production. In spite of the Indonesian-textile industry is one of the five biggest of world textile industry, the cotton fiber as the main material of the industry has not been produced in a big scale cotton cultivation. The domestic cotton fiber only supply $0.05 \%$ of the need for textile industries (Bahri 2010). The government has supported the increase of cotton fiber production through implementation of increasing cotton production programs (Hasanudin 2007). Development of cotton cultivation started through a program namely Intensive Cotton Development for Smallholders Scheme in 1978/79 which includes area of 22.000 ha (Ditjenbun 1999). The cotton cultivation was concentrated in South Sulawesi, East Java, Central Java, East Nusa Tenggara and West Nusa Tenggara. However, the program did not develop well in the context of area, which is gradually dwindling and in 2006 planting season the area was only recorded 7,000 ha, which is only $45 \%$ of the targeted area (Hasanudin 2007). Furthermore, the average productivity of seed cotton in farmer's level is very low, i.e., 300 $500 \mathrm{~kg} / \mathrm{ha}$, very much lower than the potential of the crop production $(2,000$ $-2,500 \mathrm{~kg} / \mathrm{ha}$ ). The obscurity in cotton development is due to non-technical problems, such as the unavailability of input production in a right time, and also technical problem such as insect pests' damage.

In the early development of the intensification program, we used imported seeds such as Tamcot SP 37 and Delta Pine varieties (Hasnam 1994). These varieties are smooth leaf, so that they are susceptible to the early season pest, i.e., cotton jassids (Amrasca biguttulla (Ishida)) (Hemiptera: Ciccadellidae). Organophosphate insectcides were recommended for foliar spray to control this pest. However, this insecticide sprays have caused the bollworm population, Helicoverpa armigera (Hubner) (Lepidoptera: Noctuidae), increased and caused boll damage. 
Because of the bollworm attacks that caused direct effect on the production, this bollworm has been identified as a main pest of cotton in Indonesia. This is reflected in the recommendation of pest control as a package of the program for planting season in $1971 / 72$ to 1989/90. The recommendation includes scheduled sprays for the jassid and bollworm since 45 days after planting (dap) to 105 dap with 10 days-spray interval. The first-three sprays were targeted for jassids and the remaining were for the bollworm. This practice resulted a number of seven sprays using 11.5 - $12.0 \mathrm{~L} / \mathrm{ha}$ insecticides per season (Recommendation Letter of Ministry of Agricultural for credit package of Smallholder Cotton Intensification Program on 1971/72 to 1989/90 planting seasons).

Development of integrated pest management (IPM) on cotton was then emphasized on non-chemical control. This includes the development of control technique which involves natural power, i.e. optimally functioning the role of natural enemies of the pests. In order to develop the IPM for catton, basic research activities have been done. The research activities were directed to the understanding the bioecology of the pests which includes population dynamics, inventories their natural enemies, as well as their potency as biotic mortality factors of the pest. The studies revealed that $A$. biguttula which attacks cotton in the early season is the key pest of cotton in Indonesia. The studies also identified natural enemies of cotton bollworm $H$. armigera which consists of 22 species that attack the eggs, 11 species of arthropods and 10 genera of insect pathogens which attack the larvae (Nurindah \& Bindra 1988; Indrayani \& Gothama 1988). The natural enemies of $H$. armigera could not builtup their population and well functioned as the bollworm control agents when the plantation have been chemically sprayed for controlling the jassid (Nurindah et al. 1993; 2004). Therefore, the first IPM component is the development of cotton varieties resistant to the jassid. The use of cotton resistant variety would avoid the early season insectcide sprays and give opportunity for the natural enemies to develop and then function as an effective mortality factor for the bollworm. In other words, the use of resistant variety to cotton jassid would conserve the natural enemies.

This paper discusses the development of cotton IPM in Indonesia by conserving of the natural enemies. The conservation could be done by developing cultivation techniques which include the use of varieties resistant to jassid, intercropping system, mulching, apply the action threshold concept and the use of botanical insecticide, if required. 
CONSERVATION OF NATURAL ENEMIES THROUGH COTTON IPM COMPONENTS

\section{The Use of Cotton Varieties Resistant to Jassids}

Improvement of cotton varieties resistant to jassids has been done since 1987. The improvement was done by selecting the cotton lines with hairy type, has a high potential production and a high quality of the fiber that meets with requirement of textile industry. IToFCRI has released a series of Kanesia varieties (15 varieties), which have moderately resistant to the jassid (Anonymous 2009). The hairy type of the plant, especially on the leaves which is called trichom, affects the jassid to inflexible suck the plant sap with its stylet. This physical restricttion would reduce the preference of the jassid to such plants and results in the low population of the jassid and prevents them to cause damage.

Hairy morphology of the plant is a good oviposition medium for $H$. armigera. However, larval population in such plants was always low, because population of its natural enemies was abundant. On a glabrous variety such as LRA 5166 with trichom density of 476 trichom $/ \mathrm{cm}^{2}$, population density of $H$. armigera egg was $9 \mathrm{eggs} / \mathrm{m}^{2}$ and egg parasitization level was $45 \%$, while on non-hairy cotton type such as Tamcot SP 37 with trichom density of 73 trichom $/ \mathrm{cm}^{2}$, population density of $H$. armigera egg was $6 \mathrm{eggs} / \mathrm{m}^{2}$ and egg parasitization level was $32 \%$ (Nurindah \& Sujak 2006). This high parasitization level in high egg population density was also followed by higher parasitoid species diversity than those in low egg population density (Lusyana 2005). This phenomenon indicates that the use of cotton variety resistant to jassids would increase bollworm egg population, however this increase would followed by a high mortality by its parasitoids and predators. Therefore, the use of cotton varieties resistant to jassids would conserve natural enemies and allow them to well function as mortality factor of the pests.

\section{Intercropping System with Secondary Food Crop}

Intercrop system is a cultivation practice that leads to a high biodiversity in such agro ecosystem (Jackson et al. 2010). This cultivation system is a common practice for Indonesian farmers. Cotton is always intercropped with secondary food crops such as maize, soybean, mungbean or peanut (Machfud 2002). In pest control perspective, this system has a benefit in consequence of a relatively high diversity and population of natural enemies. The number of predators of $H$. armigera in cotton intercropped with soybean has been reported higher than that in cotton monoculture (Nurindah et al. 1993; Asbani et al. 2001) and in cotton intercropped with mungbean, population of common predators such as 
Paederus sp, (Coleoptera: Staphylinidae) increased and kept the jassid and bollworm population below action threshold (Nurindah \& Sujak 2006). Lusyana (2005) also reported that species diversity of $H$. armigera egg parasitoids in such ecosystem also higher than that in monoculture habitat. The higher species diversity of egg parasitoids proceeds to enhance contribution to $H$. armigera mortality. Mortality of $H$. armigera on cotton intercropped with mungbean was $36 \%$ (egg stage), $20 \%$ (larval stage), and 36\% (pupal stage) (Nurindah et al. 2006).

Intercropping system has been proved to be an effective technique to increase insect population in the ecosystem. Habitat diversity in intercroping system would provide nectar and pollen for parasitoids and predators besides functions as a shelter for them, so that this would attract the natural enemies to such habitat (Duyck et al. 2011; Maisonhaute et al. 2010). The increase of insect population would conserve natural enemies or increase the complexity in the agro ecosystems and cause a high interaction among the present species. The dominant interacttion in a complex community is predation (Heddy \& Kurniati 1996). The increase population of natural enemies in the habitat would lead to an effective natural control of the herbivores. Therefore, intercropping system of cotton with secondary food as a compo- nent of cotton IPM could be said as an act of insect conservation.

\section{Apply Rice-Straw Mulch}

Mulching by adding biomass in an agriculture area has a positive effect to the soil. The biomass amendment would increase water holding capacity as a result of the improvement of soil physics such as porosity, permeability and mass volume of the soil (Mastur \& Sunarlim 1993). Mulching has also been reported could increase the efficiency of pest control (Mathews et al. 2002; Mathews et al. 2004; Afun et al. 1999). Mulching by using rice straw on cotton field would increase the organic matters in the soil and improve the soil fertility, as a result of soil physics and chemistry improvement, it also increase the activity of predation on $H$. armigera eggs and larvae (Subiyakto 2006). Therefore, cultivation practices of cotton in low-land after rice, where the use of rice straw for mulching is possible, would conserve the predators of cotton pests and could be relied as an effective natural power in controlling the pest. Intercropping cotton with soybean is practiceed by farmers in Lamongan (East Java) where most of the farmers rely on this natural control and do not use chemical insecticide at all. Application of rice-straw mulching on cotton intercropped with soybean and implementation of action threshold concept which consider natural enemies presence 
would increase the bollworm mortality by its predators and resulted in increaseing seed cotton production (Nurindah \& Sunarto 2008).

\section{The Use of Action Threshold}

Action threshold is a concept in pest control system; the pest population level has to be reduced by controlling the pest so that it would not cause further damage to the plant as well as economic injury. Action threshold was derived from economic threshold concept which determination of it values consider the economic factors such as market, input cost etc. These factors are fluctuated and use economic threshold concept in cotton cultivation would be very complicated. Therefore, it is necessary to use a more simple action threshold concept instead.

Monitoring of cotton bollworm $H$. armigera was done by observing the small larvae on the one third of the top plants. Topper and Gothama (1986) has developed the action threshold for H. armigera on cotton, i.e., 4 larvae/25 plants; and improved by Soenarjo and Subiyakto (1988), i.e., 4 infested plants of 25 sample plants. The number of infested plants was a simpler substance of a number of larvae observed (Soenarjo \& Subiyakto 1988). Action threshold for cotton jassid was 50\% infested plants and showing the damage. In determining the values of action threshold either Topper \&
Gothama (1986) nor Soenarjo \& Subiyakto (1988) did not consider the presence of natural enemies, whereas a numerous and a high diversity of natural enemies has been recorded in cotton intercropped with secondary food crops and a relatively high biotic mortality of $H$. armigera eggs and larvae by parasitoids and predator has been reported (Nurindah et al. 2006). These natural enemies, especially complex predators, have an important role in suppressing the pest population. Therefore, their present must be considered.

The values of action threshold then have been developed and the natural enemies presence was taken into account. The new value for $H$. armigera is 4 infested plants/25 plants and subtract the number of one infested plant observed when find every 8 predators, and fold up of it (Nurindah et al. 2008). Using this action threshold value in cotton intercropped with soybean in Lamongan, the farmers did not need to spray any insecticide to control the bollworm population to obtain the same amount of seed cotton production as per farmers used conventional control method by applying scheduled sprays (Nurindah \& Sunarto 2006). This results, in turn, manage the farmers to save up to $\mathrm{Rp} 500,000$,- per hectare for buying and applying chemical insecticides. Therefore, considering natural enemies abundance in cotton intercropping with soybean by 
conserving them would control $H$. armigera effectively, inexpensively, and environmentally friendly.

\section{The Use of Botanical Insecticides}

Botanical insecticides recommenddded as a component of cotton IPM is neem-seed extract (NSE). Formerly, input cost for insecticides in farmer level for cotton farming reached $65 \%$ of the total input cost (Basuki et al. 2002). The adverse effects of the intensive use of synthetic insecticides for a long period has been reported, e.g., insect resistance to insecticide (Martin et al. 2000; Wolfenbarger \& Vargas-Camplis 2003; Fakhrudin et al. 2003), resurgance (Satpal-Singh et al. 1995; Mohan \& Katiyar 2000; Abrol $\&$ Singh 2003), emergence of seconddary pests, and pollution to the environment (Hallberg 1989; Kelly 1995; Schultz et al. 2001). These negative impacts are a great and an invaluable loses out. The use of NSE on cotton did not have adverse effect to the predators and parasitoids (Biradar et al. 2002; Sunarto et al. 2004; Kraees \& Cullen 2008). Therefore, the NSE could be used as a substitute to the synthetic insecticides.

Cotton farmers usually grow cotton intercropped with secondary food crops and were recommended to use moderately resistant cotton varietyes to jassids. These practices actually do not need any action of pest control by applying insecticide sprays. This has been demonstrated in 350 hectares of cotton fields in South Sulawesi and West Nusa Tenggara (Hasnam et al. 2005) and 50 hectares in East Java (Nurindah et al. 2004), where in those fields did not require any insecticide spray and the cotton seed productivity was not different to, or even higher than, those of sprayed fields. However, it is not easy to convince the spray-minded farmers for not spray their cotton fields at all. Therefore, the use of botanical insecticides as synthetic insecticides substitution could be as the in-between target of alteration of the spray-minded farmer to be a more care-about-environmental farmer. This would be possible as the NSE application to the field is not different with synthetic insecticide spray.

\section{CONCLUSION}

Practice the cotton IPM components such as use of a resistant or moderately resistant cotton varieties, grow cotton intercropping with seconddary food crops, apply the action threshold by considering the presence of natural enemies and use botanical insecticide, when necessary, apparently an act of conservation of the natural enemies of cotton pests. This conservation would lead to natural control and no need control measure using insecticides. 


\section{REFERENCES}

Abrol DP, Singh JB. 2003. Effect of insecticides on the resurgence of the red spider mite Tetranychus cinnabarinus Boisduval on brinjal in Jammu, Indoa. Journal of Asia Pasific Entomology 6(2): 213-219.

Afun JVK, Johnson DE, Russell, Smith A. 1999. The effects of weed residue management on pests, pest damage, predators and crop yield in upland rice in Cote d'Ivoire. Biological Agriculture and Horticulture 17(1):47-58.

Anonymous. 2009. Varietas Unggul Tanaman Tembakau, Serat dan Minyak Industri. Malang: Balai Penelitian Tanaman Tembakau dan Serat.

Asbani N, Subiyakto, Winarno D, Sujak, Sohri. 2001. Respon pemangsa serangga hama penggerek buah kapas pada beberapa tanaman alternatif. Laporan Hasil Penelitian Proyek Penelitian PHT Perkebunan ADB Tahun Anggaran 2001. p 11

Bahri S. 2010. Impor Serat Kapas Naik 24\% untuk Volume dan pada Nilai naik 54\%. MyDigest News, http://my digestnews.blog spot.com/2010_10_10_archive.ht $\mathrm{ml}$. [accesed in 13 Oktober 2010]

Basuki T, Bambang S, Wahyuni SA. 2002. Sistem usaha tani kapas di Indonesia. Di dalam: Kapas. Monograf Balittas No. 7. Malang: Balai Penelitian Tembakau dan Tanaman Serat. Buku 1. p 55-76.

Biradar VK, Shivpuje PR, Rawale BN, Bansod RS. 2002. Effect of certain biopesticides on the population of lady bird beetle. Journal of Soils and Crops 12(1):151-152.

Ditjenbun. 1999. Pengarahan Direktur Jenderal Perkebunan pada Pertemuan Teknis Intensifikasi Kapas Rakyat Tahun 1999, Surabaya, 17 September 1999.

Duyck P, Lavigne, Vinatier AF, Achard R, Okolle, JN, Tixier P. 2011. Addition of a new resource in agroecosystems: Do cover crops alter the trophic positions of generalist preda-tors? Basic and Applied Ecology 12(1):4755.

Fakhrudin B, Badariprasad KB, Krishnareddy SH Prakash, Vijaykumar BV, Patil, Kuruvinas-hetti MS. 2003. Insecticide re-sistance in cotton bollworm, Helicoverpa armigera (Hubner) in South Indian cotton ecosystems. Resistant Pest Management Newsletter 12(2):13-16.

Hallberg GR. 1989. Pesticide pollution of groundwater in the humid United States. Agriculture Ecosystems and Environment: 26(3-4):299-367.

Hasanudin AR. 2007. Pengembangan Kapas Nasional. Makalah pada Pertemuan Koordinasi dan Sinkronisasi Pengembangan Kapas Nasional Tahun 2007, tanggal 11-12 Mei 2007 di Makassar. p 8

Hasnam. 1994. Perbaikan varietas dan produksi benih kapas. Jurnal Penelitian dan Pengembangan Pertanian 13:44-48. 
Hasnam, Nurheru, Fitriningdyah TK, Sulistyowati E, Riajaya PD, Nurindah, Sahid M. 2005. Pengelolaan Tanaman Terpada pada Kapas di Sulawesi Selatan dan Nusa Tenggara Barat. Laporan Hasil Kegiatan TA 2004. Malang: Balittas. 35 p.

Heddy S, Kurniati M. 1996. Prinsip Dasar Ekologi: Suatu Batasan Tentang Kaidah Ekologi Dan Penerapannya. Jakarta: PT Raya Gra-findo Persada, Jakarta.

Indrayani IGAA, Gothama AAA. 1988. Survey of entomopathogens of cotton pests in Indonesia and preliminary studies on microbial control of Heliothis armigera. Cotton IPM Research Workshop, Vol. 1: Crop Protection. AG: DP/INS/83/ 025, Field Document 8:73-89.

Jackson L, van Noordwijk M, Bengtsson, J, Foster W, Lipper L, Pulleman M, Said, M, Snaddon, J, Vodouhe, R. 2010. Biodiversity and agricultural sustainagility: from assessment to adaptive management. Current Opinion in Environmental Sustainability 2(1-2):80-87.

Kelly AG. 1995. Accumulation and persistence of chlorobiphenyls, organochlorine pesticides and faecal sterols at the Garroch Head sewage sludge disposal site, Firth of Clyde. Environmental Pollution 88(2):207-217.

Kraess H. Cullen EM. 2008. Insect growth regulator effects of azadirachtin and neem oil in survivorship, development and fecundity of Aphis glycine (Homop- tera: Aphididae) and its predator, Harmonia axyridis (Coleoptera: Coccinellidae). Pest Management Science 64:660-668.

Lusyana NR. 2005. Keragaman parasitid telur Helicoverpa armigera pada tanaman kapas (Gossypium hirsutum L.) monokultur dan tumpangsari di Asembagus, Kabupaten Situbondo [Skripsi] Malang: Universitas Negeri Malang.

Machfud M. 2002. Budi daya kapas di lahan sawah. In: Monograf Balittas No 7: 101-108. Malang: Balai Penelitian Tanaman Tembakau dan Serat.

Maisonhaute J, Peres-Neto P, Lucas É. 2010. Influence of agronomic practices, local environment and landscape structure on predatory beetle assemblage. Agriculture, Ecosystems \& Environment 139 (4):500-507.

Martin T, Ochou GO, Hala N, Klo F, Vassal JM, Vaissayre M. 2000. Pyrethroid resistance in the cotton bollworm, Helicoverpa armigera (Hubner), in West Africa. Pest Management Science 56(6):549-554.

Mastur, Sunarlim N. 1993. Pengaruh drainase/irigasi dan mulsa jerami padi terhadap sifat fisik tanah dan keragaan kedelai. $R i$ salah Hasil Penelitian Tanaman Pangan 1:67-74.

Mathews CR, Bottrell DG, Brown MW. 2002. A comparison of conventional and alternative understory management practices for apple production: multitrophic effects. Applied Soil Ecology 21(3):221-231. 
Mathews, CR, Bottrell DG, Brown MW. 2004. Habitat manipulation of the apple orchard floor to increase ground. dwelling predators and predation of Cydia pomonella (L.) (Lepidoptera: Tortricidae). Biological Control 30(2):265-273.

Mohan M, Katiyar, KN. 2000. Impact of different insecticides used for bollworm control on the population of jassid and whitefly in cotton. Pesticide Research Journal 12(1):99-102.

Nurindah, Bindra OS. 1988. Studies on biological control of cotton pests. Industrial Crops Research Journal 1:59-63.

Nurindah, Sudarmo S, Soebandrijo. 1993. Pengaruh tumpangsari kapas dengan palawija terhadap populasi predator serangga hama kapas. Di dalam: Prosiding Diskusi Panel Budidaya Kapas + Kedelai, Malang, 10 Desem-ber 1992, Seri Pengembangan, No.7 1993:55-60.

Nurindah, Subiyakto, Sunarto DA, Soebandrijo, D Winarno, SriHadiyani, Basuki T, Sujak, Parmono DH. 2003. Optimalisasi pemanfaatan musuh alami dalam pengendalian serangga hama kapas. Laporan Teknis Intern Proyek Penelitian PHT PR TA. 2003.

Nurindah, Sunarto DA, Basuki T, Sujak, Parmono DH. 2004. Pengembangan model PHT Helicoverpa armigera pada kapas rakyat. Laporan Teknis Intern Proyek Penelitian PHT PR TA. 2003.
Nurindah, Sunarto DA, Sujak. 2004. Pengaruh penyemprotan insektisida terhadap prekembangan populasi laba-laba dan wereng kapas Amrasca biguttulla (Ishida) (Homoptera: Ciccadelidae). In Soebandrijo et al. (Eds) Prosiding Lokakarya Pengembangan Kapas Dalam Rangka Otoda; Malang, 15 Oktober 2002. Bogor: Badan Litbang Pertanian, Pusat Penelitian dan Pengembangan Tanaman Perkebunan p. 62-66.

Nurindah, Sunarto DA, Basuki T, Sujak, Parmono DH. 2005. Penerapan teknologi PHT pada kapas tumpangsari dengan palawija. Laporan Hasil Penelitian TA 2005. Malang: Balittas. 27 p.

Nurindah, Parmono DH, Sujak. 2006. Faktor mortalitas biotik Helicoverpa armigera (Hubner) pada kapas tumpangsari dengan kedelai. In Sulistyowati E. et al. (Eds.) Prosiding Lokakarya Revitalisasi Agribisnis Kapas Diintegrasikan dengan Palawija di Lahan Sawah Tadah Hujan; Lamongan, 8 September 2005, Lamongan: Pusat Penelitian dan Pengembangan Tanaman Perkebunan. p. 110-117.

Nurindah, Sunarto DA. 2006. Efektivitas beberapa predator terhadap Helicoverpa armigera (Hübner) pada kapas tumpangsari dengan kedelai. Jurnal Penelitian Tanaman Industri 12(3): 116-120.

Nurindah, Sujak. 2006. Pengaruh sistim tanam tumpangsari kapas dengan palawija terhadap po- 
puasi predator. Laporan Hasil Penelitian TA 2006. Malang: Balittas.

Nurindah, Sunarto DA. 2008. Ambang kendali penggerek buah kapas Helicoverpa armigera dengan mempertimbangkan keberadaan predator kapas. Jurnal Penelitian Tanaman Industri 14(2):72-77.

Satpal-Singh K, Kushwaha S, Sharma, PD. 1995. Resurgence of rice leaf folder Cnaphalocrocis medinalis Guenee due to application of carbofuran granules. Indian Journal of Entomology, 57(4):366-372.

Schulz R, Peall SK, Dabrowski J. M, Reinecke AJ. 2001. Spray deposition of two insecticides into surface waters in a South African orchard area. Journal of Environmental Quality 30(3):814-822.

Soenarjo, Subiyakto. 1988. Sampling for cotton insects: 2. Sampling for monitoring of Heliothis populations based on its withinplant distribution. Project for Development of Integrated Cotton Pest Control Programme in Indonesia, AG:DP/ INS/83/25. Field Doc. 11. 20 p.

Subiyakto. 2006. Peran mulsa jerami padi terhadap keanekaragaman arthropoda predator dan manfaatnya dalam pengendalian serangga hama kapas pada tumpangsari kapas dan kedelai [Desertation]. Malang: Universitas Brawijaya.

Sunarto DA., Nurindah, Sujak. 2004. Pengaruh ekstrak biji mimba terhadap konservasi musuh alami dan populasi Helicoverpa armigera Hubner pada tanaman kapas. Jurnal Penelitian Tanaman Industri 10(3):89-95.

Sunarto DA, Nurindah, Parmono DH. 1994. Perkembangan populasi predator pada beberapa varietas kapas. Buletin Tembakau dan Serat 3(6):35-39.

Topper CP, Gothama, AAA. 1986. Integrated Pest Management of Cotton Pests in Indonesia. Report on cotton pest threshold trials in the 1984/85 season, Volume One. Malang: Balai Penelitian Tembakau dan Tanaman Serat.

Wolfenbarger DA, Vargas-Camplis J. 2002. Profenofos: response of field. collected strains of bollworm and tobacco budworm in South Texas, USA and Mexico. Resistant Pest Management Newsletter 11(2):11-13. 